\title{
RC²@Craftsvilla.Com \\ Craftsvilla is Revolutionizing through Co-creation: Creating Value for Stakeholders
}

\author{
Ruchi Pathak \\ Meghna Sharma \\ R. Sujatha
}

Amity University, Noida, India

\section{Keywords}

E-commerce, disparity, stakeholder engagement, co-creation, value creation

\begin{abstract}
Monica and Manoj, founders of Craftsvilla.com, once had an opportunity to interact with rural artisans and designers, in her road trip to Kutch. While interacting, they realized that the middlemen involved in this unorganized retail business were paid very less for the products. The single reason for this disparity they found was the process of taking the art form to retail stores (middleman involved). Most of the artisans, because of no return from the business, want to disengage their future generations to learn the art.

The reasons for the extinct includes illiteracy, inability to reach the customers, lack of awareness to understand customer needs and customization, better bargaining power of the middlemen, lack of awareness about the government support programs, lack of mentors to guide them, poverty, and so on. With the passion for Indian culture and the urge to benefit the artisan-producers, they decided to work on an e-commerce business model, craftsvilla.com, a $\$ 200$ million start-up. The idea was to create a platform where the artisans could directly connect with consumers and earn a good livelihood. The present case study on Craftsvilla. Com is built under the context to explore the concept of co-creation in e-commerce industry and the business opportunities for Craftsvilla through co-creation. The data for the case study was collected over a period of 10 months, starting from October 2015 to August 2016.Data collection primarily was through regular interaction with the founders, artisans, employees, and customers of Craftsvilla. Learning from the case will help to identify various methodologies to adopts cocreation opportunities by engaging stakeholders.
\end{abstract}

Corresponding author: Ruchi Pathak

Email address for corresponding author: ruchigautampant@gmail.com

First submission received: 28th February 2017

Revised submission received: 18th April 2017

Accepted: 22nd May 2017

\section{Introduction}

"Customer experience is defined as the sum-total of conscious events, as a coordinated series of interactions between a customer and a brand to accomplish anything. Above all words - a customer experience is defined by the customer, for the customer, at each touch-point, each time." - Esteban Kolsky

Monica loves handmade jewels and organic products, and Manoj loves to travel. On a road trip to Kutch in 2011, where Monica bought few of the ethnic handicrafts and home décor products for her. The couple was overwhelmed by the designs and efforts put in by artisans. Monica was surprised with the price of these products, as the artisans quoted it very low. After having detailed conversations with some of the artisans, they understood that what is sold in the market is very expensive because of the middlemen involved. These middlemen give them a raw deal and offer the same products in the market at higher prices. With their inquisitiveness to know more, the travelers became researchers and learnt a few odder deals about the reality of this unorganized retail market. All the artisans, the duo interacted, narrated their grief. Monica and Manoj felt that these are 
probably the last generation engaged in this exclusive traditional art form from India. The reasons for the extinction of these art forms includes illiteracy, inability to reach the customers, the lack of awareness in understanding customer needs and customization, better bargaining power of the middlemen, lack of awareness about the government support programs, lack of mentors to guide them, poverty, and so on.

With the passion for Indian Culture, Monica felt the need to promote these heritage ethnic homemade products. They started brain storming with the only objective to benefit the artisanproducers. They decided to work on an e-commerce business model; the idea of creating a platform where the artisans could directly connect with consumers and earn a good livelihood. The online platform will showcase a variety of products, which would not have been possible through a shop. As they came back home to Mumbai Manoj took off from his regular job routine as a Principal at Nexus Venture Partners, as the duo was serious about executing the idea. The couple wanted to have a fair deal and give the artisans their due and this is how they sowed the seed called 'Craftsvilla.com, once \$200mn start-up. The Founder's passion is strongly visible with their tagline "A market place to discover India". It has today expanded beyond India across the shores to Malaysia, US and Canada, Australia and New Zealand. Today they stand tall with more than 8 categories of products and more than 6,410,199 Facebook likes ${ }^{i}$ and 46+ online pages. With this backdrop, the present case study on 'Craftsvilla.com' tries to explore the relevance of Co-creation in e-commerce Industry and to explore the business opportunities for Craftsvilla through Co-creation.

\subsection{Craftsvilla Business Encounters}

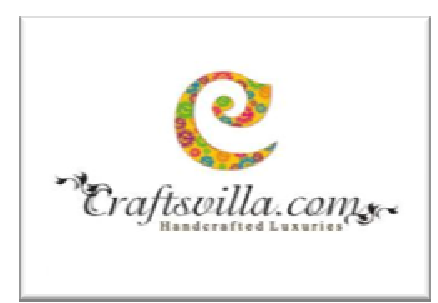

There are parts and parcels that every start-up carries with it. But there are very few people who understand that starting something new is easy but getting into the roots of market requires practice, patience, time, and money. Challenge is not just to establish the self but to empower customers with better and distinctive services with greater demand placed in the product.

Monica and Manoj had the business plan, but the couple had "low funds" and their first two years were chaotic; they ate through funds and did all the things a start-up should not do'. The startup had completely exhausted US\$1,500,000 in the early stages-Series A of funding from Nexus Venture Partners and Light Speed Ventures-which resulted in couple selling their home and downsizing employees to a 10-member team. Another challenge was to connect the designers with the technology platform to expand the range of their handmade products and to enhance customer connectivity. Initially they bought products from artisans and sold them online.

Gradually, founders earned their trust and today they have over 75,000 organic products on the portal. For the first two years, venture capitalist showed no interest in investing in this start-up. They viewed Craftsvilla's pitching stories as worst, and that they were trying to create just another e-bay in India. As narrated by Manoj- Ethnic clothes were not considered to be a sexy category; which played as a weak pitch for requesting funding. As capitalists felt that our target group was aunties (the elder ladies)."

Being a start-up, it was never easy for founders to lay off people. Initially they were giving double the amount in terms of salaries to their employees, later-on they started asking people to leave from different parts of the business and retained a team of 10 strong (brains only with prior experience and with business acumen) people to survive on. The focus of the founders changed from managing people to giving away discounts to the consumers. It was done to gain strong seller acquisitions, using technology to automate the online selling systems and customer care, to automate

${ }^{1}$ http://articles.economictimes.indiatimes.com/2015-12-28/news/69356583_1_50-lakhs-nexus-venture-manoj-gupta (accessed on 25 May 2016). 
inventory updates, to track numbers in bulk, and in starting even charging sellers for marketing. It took patience, practice, time and money. Initially, they felt being broken into pieces from offering excessive discounts, seeing no repeat customers, and acquiring sellers with fake shops. This caused them a waste US\$ 74,173 in cash each month. The next challenge was the time taken for the exchange of products, which was also turning the customers off. Although Craftsvilla had a 7-day return policy, but there were gaps. For e.g. if a product was returned by a customer, it would take more than the promised time to reach back to the customer, with an exchanged product. To ensure a smooth and timely procedure, they recently acquired Send, a logistics company, which is now taking care of each aspect related to the delivery at Craftsvilla.

The major challenge for Craftsvilla was working with unknown brands in the ethnic categoryii.It led to a lot of struggle in gaining trust of consumers, who were unaware about these brands. Craftsvilla made sure that the seller quality is maintained by adopting the quality check and packaging part, even when they are scaling up. Unlike other the competitors, they always had a controlled marketplace and checked inventory and product quality of all on-board sellers periodically. Monica personally ensured double quality check for all the products ready to be delivered. During this period, the primary challenge identified was how to scale up audit processes with no significant increase in costiii.

\section{Indian E-commerce Industry}

In 2015, India's e-commerce industry's worth was $\$ 23$ billion, and it has grown up by 67 percent in 2016, representing almost $\$ 38$ billion dollars in worth. There is a tremendous increase in online shopping and mobile commerce ${ }^{\text {iv }}$. A lot of Shift in consumer buying behavior is noticeable. Huge shift is buying everything online rather than giving preference to visiting a shop personally, has created a boom. This has further led to a healthy competition amongst e-commerce players. Eshopping portals have given birth to the community of aggressive buyers. The growth of online participation has a great impact on the buying decision of these buyers. Craftsvilla has started seeing a 90 percent repeat customer base, with their strong social media presence. They currently have over six million users on Facebook only. Their primary cost is marketing and the expenses on fixed costs do not exceed more than 2-3 percent of their annual income. Their current revenue per employee is $\$ 14,300 v$.

\subsection{Contemporary Customers in India}

Young people in India spend 16 percent of their disposable income online, and an estimated 828 million Indians are less than the age of 35 in 2015. These people increasingly use mobile devices to shop, and the increasing penetration of smart phones in the country can only help the cause of ecommercevi.D.S. Rawat, Secretary General, Assocham, says, "The customer is connected $24 \times 7$ through their smart phones, tablets and other mobile devices, which is leading to a gradual evolution of e-commerce into mobile commerce and there is an issue of convenience which also leads to impulsive buying." In 2015, 78 per cent of shopping queries were made through mobile devices, compared to 46 per cent in 2013 vii.

\subsection{Ethnic Wear Market}

Ethnic wear market is expected to grow at a compound annual growth rate(CAGR) of 8 percent and reach $\$ 19,600$ million in 2018 viii. Therefore, a huge potential for ethnic wear websites is lying ahead. However, the success depends on how different one player from the other is. There are few online parameters explored by Prashant, Sujatha and Ruchi in a research paper are real product details, cumulative ratings and understand about the brand, explaining the expectations of the consumer on the online content such as product benefit, deals, cautious syndrome of the consumer before deciding to buy a product or service and Currently, helping customers to understand features of new products or gain comparative analysis of products(Devedi, 2017).Currently, Craftsvilla is getting 70 percent of their traffic from mobile and 30 percent from desktop. Therefore, to consider 
above mentioned online preferences by customer must be considered byCraftsvilla.com. It is an online marketplace for ethnic products among the few Indian start-ups to have remained afloat and scaled without raising funds in 2013 and 2014 ${ }^{\mathrm{ix}}$."Craftsvilla's growth using a lean cost structure is rare in the Indian e-commerce ecosystem"

\subsection{Online Shopping Cycle}

It is shown in the figure below as two-way process: It is believed that customers surf through different websites to find out about the product they have in mind. Else they follow the navigation provided in a promotional mail they get in their inbox, or the advertisement/promo they see on websites.

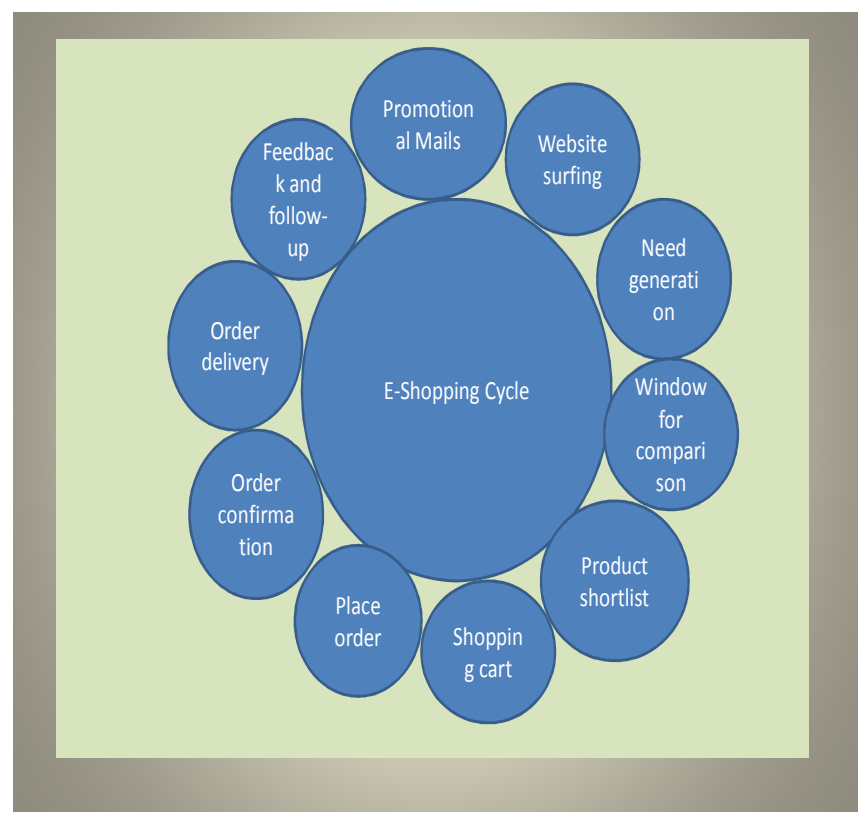

Figure 1: Online Shopping Cycle, Source: Researcher's Work

\subsection{Craftsvilla's Growth}

Recently Craftsvilla has three acquisitions. First one is on-demand logistics enabler Sendd, which they acquired on 1 February 2016. The all-equity deal values the Kae Capital-backed start-up at close to $\$ 5$ million (around INR 34 crore). This deal took place with a vision to make Sendd one of the largest logistics companies. The key focus now will be on delivering volume, which can only be achieved by B2B play. Three major factors that Craftsvilla (on the logistic front) and Sendd conjointly would be focusing on are reducing the shipping cost, delivery time, and returns. This acquisition has helped Craftsvilla reach smaller towns and villages that are known as ethnic heartland of India. They acquired an ethnic food online retailer, placeoforigin.com, on 25 February 2016. It was the second major acquisition by Craftsvilla within a month. The idea behind these acquisitions is to build Craftsvilla into a one-stop destination for all ethnics needs. This Bengaluru-based portal, which retails sweets, savories, and other local specialties from across the country, fits into Craftsvilla's vision of building the foods category into a huge one for the company, and it plans to go public in next two years. Third acquisition by them is a clothing rental start-up, F2SO4, on 28 April 2016.It offers branded and high-end designer clothes on rent, with the idea to make luxury clothing affordable to wear by everyone. After raising INR 220 crore (US\$ 33 million approx.) in November 2015, Craftsvilla has taken multiple bets to increase its product portfolio, on-boarding men's ethnic wear and expansion to South East Asian markets. The marketplace was also piloting customized stitching for buyers on the platform. The current acquisition will be a part of the technology for ease of sharing designs between buyers and the tailors ${ }^{\mathrm{xi}}$.Craftsvilla founders aim to acquire Ayurveda 
category in futurexii.Craftsvilla's success has been not just that of buying, selling, and retailing products. They stand different from others and have crafted success by having an integrated business model (depicted below) of co-creating with stakeholders. Journey has not been as easy for them. Monica has been putting in a lot of efforts to be consistently in touch with offshore and onshore customers and their changing demands. Her focus has been on training artisans to be technology savvy as well as deliver the best products by including customer ideas, i.e. delivering what customers want and not what they can make.

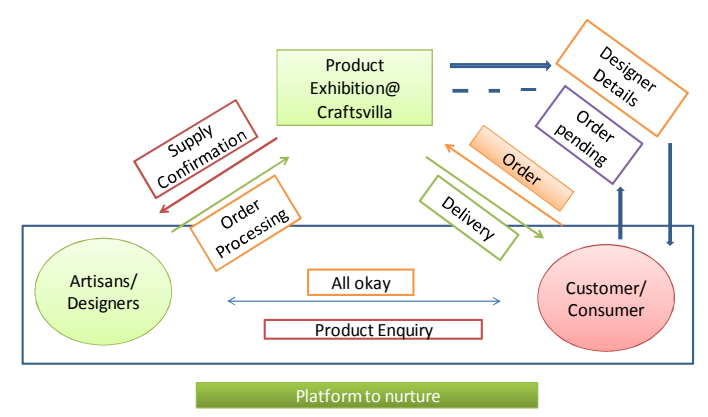

Figure 2: Craftsvilla's Business Model, Source: Researcher's work

This research is intended to study and understand the existing business model and suggest current and future acquisitions are done to enable easy payments, reconciliation for artisans as well as to enable designers for catalogue management themselves. The idea behind is to enrich Craftsvilla's digital platforms to third party users to create an additional stream of revenue ${ }^{x i i}$.

\section{Co-creation}

"If a customer likes you and continues to like you, they will do business with you. If they don't, they won't."

- Paul Greenberg

As coined by, Prahlad and Ramaswamy, Co-creation is a management initiative, or a form of economic strategy, that brings different parties together (for instance, a company and a group of customers), to jointly produce a mutually valued outcome (Prahlad, 2004)(Lindegaard, 2013). “Cocreation projects between social entrepreneurs and employees of traditional companies are a powerful way to ensure the employees' satisfaction with their jobs". Co-creation allows and encourages a more active involvement from the customer to create a value rich experience". Cocreation grants consumers free rein to work with company-provided resources in the production of their own value offerings. It is a product (or service) development approach where users and customers are actively involved and take part in the design of a new offering. "co-creation by sharing experiences, all the parties involved will acquire a deeper understanding of what is happening on the other side of an interaction, enabling them to devise a new, better experience for both sides". "Cocreation projects between social entrepreneurs and employees of traditional companies are a powerful way to ensure the employees' satisfaction with their jobs"xiv. Co-creation allows and encourages a more active involvement from the customer to create a value rich experience" ${ }^{\prime \prime v}$. Cocreation grants consumers free rein to work with company-provided resources in the production of their own value offerings ${ }^{x v i}$. It is a product (or service) development approach where users and customers are actively involved and take part in the design of a new offeringxvii. "co-creation by sharing experiences, all the parties involved will acquire a deeper understanding of what is happening on the other side of an interaction, enabling them to devise a new, better experience for both sides"xviii. 


\subsection{Understanding Trend of Co-creation}

Firms are involved in co-creation for the following three reasons as suggested by a report on cocreation by European commission are: 1) For their own benefit; 2) Deploying the platform for cocreation in service of others; 3) Co-creating for production of own products and third parties(Cocreation design as a new way of value creation, 2014). Craftsvilla has crafted own process of cocreation through the followings:

- Beautifying the raw products with designers.

- Creating a visibility of Indian ethnic products through their website platform.

- Creating a market for ethnic products globally.

- Customers get the freedom to put in ideas on what product is required and the variants they wish to see.

- Providing a platform for direct communication between designers and customers to facilitate idea generation and adoption.

\subsection{The Advantages/Edge}

For Craftsvilla, the advantages in this case are1) the improved product quality,2) innovative efforts that are taking place to meet consumer needs,3) product outreach from remote area of India to global places,4) increased competitive advantage through different product,5) focused logistics, and 6) diversified acquisition of business to facilitate the process of co-creation.

Their role of co-creation stands in service of others as they have deployed their platform for creating a B2B platform. Key driver for this co-creation includes 1) making more user-friendly webbased technology, 2) accessing customers' knowledge with least difference, and 3) analyzing shopping behavior and shifts in consumer buying behavior. Contemporary online retailers have created own community of buyers. People on such places/platforms discuss their likes and dislikes about a company that further serves as a chance for improvement. Consumers feel delighted as their bargaining power has increased. Online shopping portals' approach is more of a customer centric then company centricix. From Monica's perspective, reasons for this uptake are 1) to save Indian culture and 2) provide the talented individuals platform to show their talent to the world. So, that they get the fair amount for their work with least minimum margin in between. All their website promotions have been consumer centric with upholding the cooperation for beautifying the raw products (Please refer to Figure 2).

\section{Value Proposition Model}

Craftsvilla has its own value business model which is based on its growth strategy of backward integration from growing artisan portfolio to growing customer. This model progresses towards building an entire value chain from producers to end customers. Very few people are involved in this process as compared to traditional retail models used by other websites. Key players forming this value chain are only artisans, Craftsvilla team, and customers. Products flow from designers to the Craftsvilla studios. Craftsvilla shoots the products at their studio, helps artisans to upload the pictures, and provide warehousing, packaging, and dispatch facilities. They also train artisans to manage their own online accounts.

Once the order is placed on the website, the information immediately reaches the designer. In addition, the mail confirming the order includes the contact details of the designer so that the customers can discuss product variations directly with the producer. Manoj Gupta, has also ensured that his business model is focusing on increasing checks and balances for sellers that reduce chances of creating shortcuts. However, this should not be a concern for the founders and the portal because once a customer opts for shortcut they may have to compromise with quality. As quality check at Craftsvilla is a two-round process performed at the end of completing the order and before dispatch. 


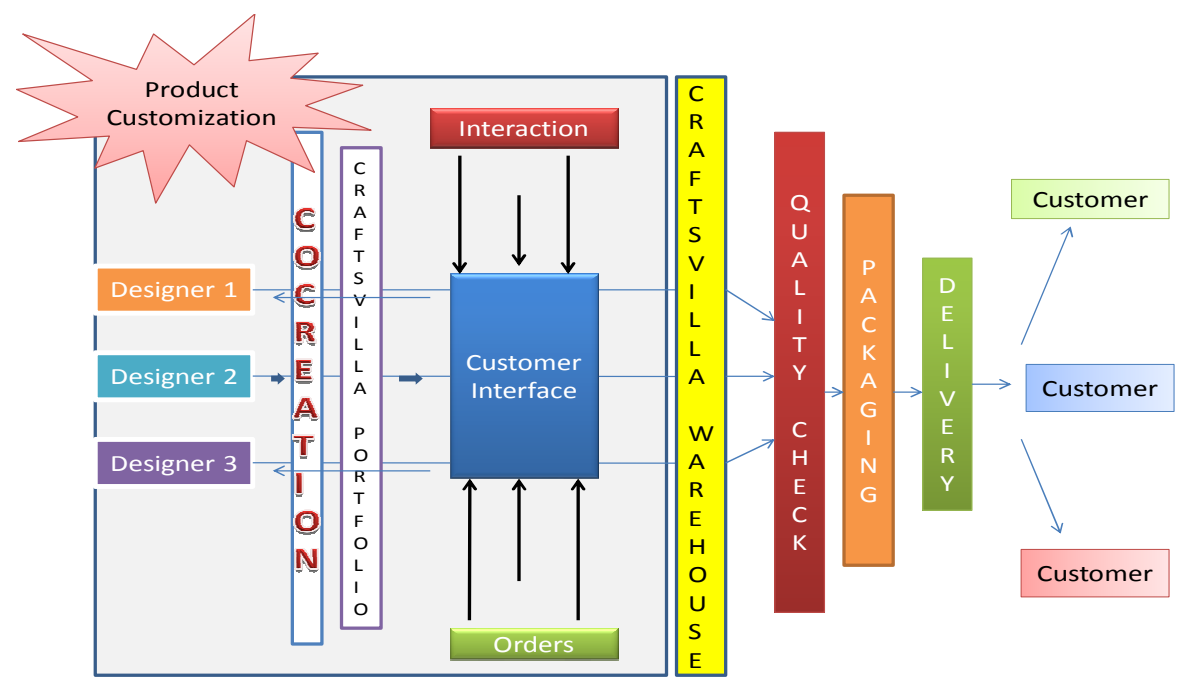

Figure 3: Figure 3: Value Chain Model of Craftsvilla. Source- Researcher's work

\subsection{Value proposition for crafters:}

Craftsvilla.com is an online marketplace with the largest selection of unique products from India across categories, including jewelry, home décor, accessories, and apparel. Craftsvilla has brought global consumers access to Indian products that are unique, not available through any other medium globally, and delivered at an affordable price with quality guaranteed ${ }^{x x}$.Their present customer acquisition strategy ensures they do not incur more than INR 100 (US\$ 1.50) for acquiring each consumer. Craftsvilla presently takes a 20 percent commission on each transaction and has over 25,000 artisans and designers on-board ${ }^{x \times i}$.

\subsection{Value proposition for customers}

Craftsvilla has made its customer care scalable by creating an online mechanism for dispute resolution and by enabling direct customer-seller communication. In addition, they have made finance function scalable by creating automatic payments to sellers and by integrating SAP with their webstore for automatic invoicing and accounting of payments. They have zero spent on advertisement, and the strategy to attract customers is through active blogger community, active search engine optimization, and heavy usage of social media platforms. This value business doesn't only have horizontal reach but has a geographical reach too.

Craftsvilla.com has transcended traditionally disorganized/lost ethnic craft on an elevated platform and has enabled micro-entrepreneurship at a scale. Customers gain access to well-designed, high-quality products at reasonable prices and craftspeople get fair prices by removing intermediaries. With increasing global travel, cultural integration, and desire for bespoke design, this platform can now serve customers and craftspeople across nations ${ }^{\text {xxii. }}$.

\section{Craftsvilla's cocreation journey}

To Cocreator is innovation in products and services with empowered consumers and external partners. Frugal Innovations are promoted through a structured cocreation model as proposed by the present study. The team made several critical decisions with crystal clear conviction that, in hindsight, worked well for the company. These include the following:

- A clear commitment to be a marketplace versus a retailer (or mix of the two).

- With this clarity, focused aggressively on aggregating sellers and building strong technology-led capabilities for the on-board sellers and allow them to create together and sell through the Craftsvilla platform.

- Letting the diversity of supply-drive demand instead of using a discount-led approach. 
- Kept the team lean and fixed cost burden low. Manoj and Monica gave it everything they had and built a young and highly motivated team around them - a team of 15 people till a couple of months back! Conventional wisdom might have argued for a seasoned and pedigreed team that allows for accessing capital faster.

\subsection{Craftsvilla's Key Differentiators Leading to Co-creation}

- Frugal innovation as is practiced in emerging markets purposefully targets the bottom and then makes its way up to other levels to benefit all users. There is potential to demonstrate that this is a new kind of innovation process which leverages institutional voids and resource constraints, debunks heavy R\&D investment claims, and achieves profitability from BOP consumers ${ }^{x i i i}$.Craftsvilla.com uses a marketplace model to capture the regional variations of India, and they are different from other online players because of the following reasons:

- There is a platform provided by Craftsvilla where the direct communication between artisans and consumers takes place.

- In addition to order placed by customers, artisans get regular feedback on product customization/ personalization.

- Craftsvilla is not just providing supply confirmation but is helping designers to incorporate the ideas given by customers in the products through formal training programs.

- When the product is ready for delivery, packaging and quality check aspect is taken care of by Craftsvilla only.

- One differentiation is the focus on Asian supply, especially, with strength in India.

- Business model handholds artisans and designers in bringing them online by helping them with photo shoots, content writing, web upload, and even in some cases helping them in inventory management and dispatches.

- Craftsvilla has introduced Internet to artisans of India, and has created an online market for them.

- Craftsvilla now operates with the help of a solid team including technical force, seller acquisition specialists, and marketing professionals.

- They have established "Craftsvilla Studios" in various parts of India which serve as local hubs for artisans.

- They have created a platform that enables cocreation to happen between buyers and sellers in a very simple way.

\subsection{Implementing Co-creation @ Craftsvilla: Payoffs}

- It has been announced as one amongst top-five ecommerce companies in India because of its gross merchandise volume scale.

- Has grown four times in scale in the last six months, as on date and continuous that trajectory.

- It has turned the corner on cash flow break-even while achieving scale and growth.

- This performance by Craftsvilla is exceptional by all standards and is driven by three key factors as follows:

(i) Fundamentally strong business model

Craftsvilla has gone through the hard part of getting the platform to scale, and the quality of the current business is reflected in several metrics. Marketing spent has stayed below 10 percent of sales while revenue has grown four times in last six months; organic sources contribute two-thirds of the total traffic; Craftsvilla has an active seller base of 12,000 artisans who by themselves upload and manage an inventory base of 2 million stock keeping unit on the platform; a highly fragmented seller base; and median 
contribution of top-10 sellers to gross merchandise volume is 1.5 percent and beyond top10 none of the sellers contributes more than 1 percent of sales.

(ii) Extraordinary perseverance and focus of the founders

Instead of going down the path of driving gross merchandise volume through discounting (at the cost of margins). Manoj and Monica chose to go through the harder path of building the core of the business by bringing thousands of suppliers across the country on to one platform and helping them sell their products online. To continue to do this for multiple years, while the industry is still rewarding a capital-led growth path, it needs strong founders like Monica and Manoj who have deep conviction.

(iii) Adopting co-creation has made a boom

Craftsvilla had reported a PAT profitability of 1.2 percent in their second quarter, 2013, financial results. Craftsvilla.com was targeting gross sales of 100 million in the FY14 (2013-14) with PAT profitability of close to 4 percent. In Indian ecommerce environment where big ecommerce companies like Flipkart and Snapdeal are bleeding cash on every sale, Craftsvilla.com is the rising star with a capital efficient and profitable business marketplace model. With a growth of more than 10 percent month-on-month and with a differentiated positioning as a leader in Indian products, focused on a unique consumer segment that is primarily women in India and customers outside of Indiaxiv. They should continue to invest more in technology and online collaborative platforms to make Craftsvilla the best place to buy and sell and create products online.

\section{Relevance and Significance}

In today's world of information and communication technology, Internet is forcing companies to think differently about value creation and to be more responsive to consumer experiences. In fact, the balance of power in value creation is tipping in favor of consumers ${ }^{\mathrm{xxv}}$.Consumers expect variety and are open to experience change. "Something new and different" is the key to keep customers loyal and when it is not, customers do not hide their disappointment. Businesses, therefore, are now transforming as per customers 'viewpoint. Open innovations have encouraged organizations to embrace crowdsourcing (Airtel, Uber, OLA), consumer-led innovations (Kohler)(Pathak \& Sharma, 2016), and co-creation (Craftsvilla.com). Another advantage for online portals is that they gain greater consumer awareness and quicker visibility in the market. Co-creation is a strategy to earn customers, their ideas, and support to develop a product. In this process people instantly transit from just thinking about a product to creating a product. Customers feel returning to the websites where their ideas are welcomed and to believe online traffic is getting diverted to companies where ideas are heard, evaluated, and included in the formulation of product processes. In keeping with such a strategy, Craftsvilla has come up with co-creating with customers. The present case study on co-creation will not only enable online players to revisit their strategy but also be useful in business schools in understanding co-creation, designed specifically for innovation-led courses. Case study on Craftsvilla enables organizations to learn the art of "welcoming the customers" and "converting them into repeat/loyal." The proposed model has not been designed by keeping only Craftsvilla in mind rather it has the potential to benefit every e-com player willing to have creative customers on-board.

\section{Conclusion}

In the red ocean of competent online players, Craftsvilla has created a blue ocean for itself where they have no competition and are continuously rising. Craftsvilla has created a blue ocean with cocreation which is creating value simultaneously for both-the buyers and the company. In this manner, they have become the value pioneers. This innovation-in product, service, and/or delivery - must raise and create value for the market. Craftsvilla has made it successful to change the mindset of Indian customers from unattractive products to most-demanding ethnic products. Craftsvilla is equally focused on simultaneously reducing or eliminating designers that are less 
valued by customers. Moreover, co-creation does not only give a boost to innovation capacity of the firm, but it also enhances the scope for further improvisation and upbringing the firm to serve and cheer.

\section{a) Customers}

World is full of "speed and innovation" happening all around. Now-a-days, what customers expect from any website is the variety and the speed of delivery. Portals having less focus on either of these two become a second choice for its crowd. What matters the most is to connect with the customers, to know before them what they want. Co-creation adds a star to it. People, knowingly or unknowingly, take part in these activities. The need is to make them aware that yes organizations are co-creating and they need external inputs as they matter the most. It is not the product or services that will keep the e-commerce alive rather its customers, and to keep updated with them, will keep it alive. When it comes to internal customers, that is, employees, these are the ones whose passion and enthusiasm keeps Craftsvilla going good. Founders welcome the idea given by their employees and recognize them timely.

b) Investors

They invest where the huge potential is seen at number one and where the firm has considerable market share they invest on at number two. Investors always check the weight an idea has and after putting up the money and to generate the capital further. Co-creation is the best way to show the development path for the money, investors are investing. In this whole process, investors keep intact with both vision of the founders and the future customers. As a support of these concerned investors only Craftsvilla could make all acquisitions so far. It is the result of the mutual understanding of the board and the customers.

c) Artisans/Designers

They are still innocent on the part how well they are known to the world. They still focus on the hard work they put in their products and the amount they will be getting on the deals. Two prime motivating factors for them are 1) getting known to the world and 2) orders from worldwide. The feedback received from the customers helps the artisans in two ways. Primarily, it acts as an input for improving the value proposition of the existing product. Later, it helps them to understand the degree of likability of the product by the customer. Artisans love to customize products as per their customers, be it adding few more colors or glitters to a product or the personalized packaging and personal messages on the gift boxes.

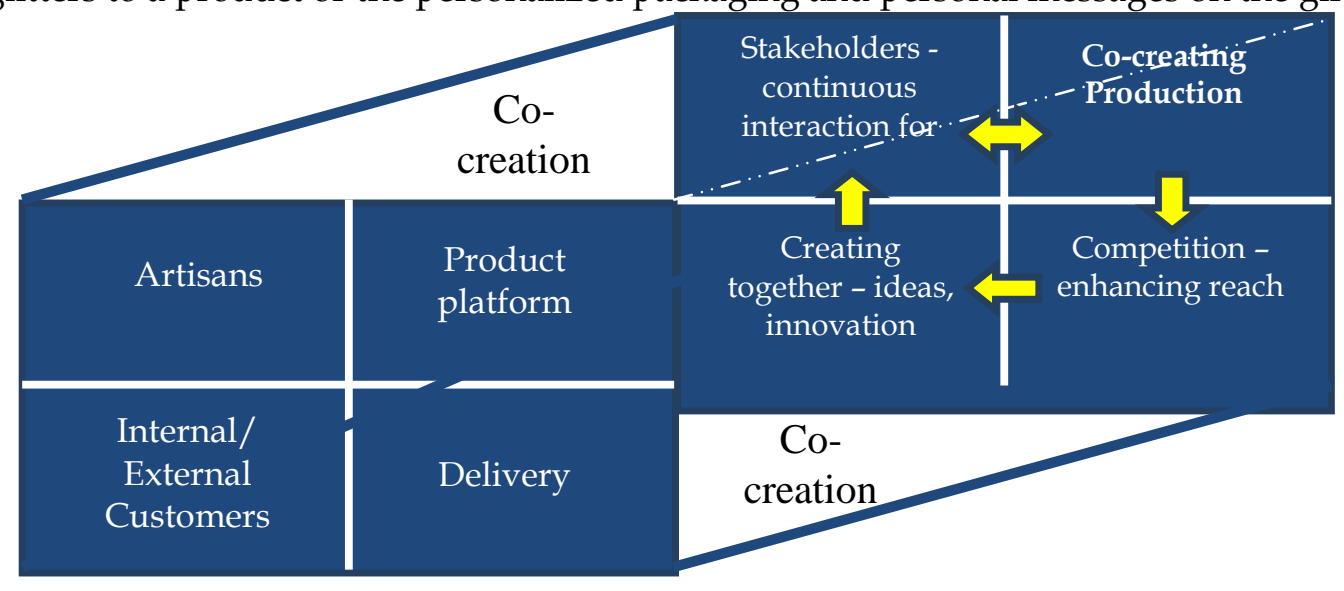

Figure 4: Business Model to Co-create, Source: Researcher's Work 


\section{d) Founders}

They are first, own kind of entrepreneurs with primary focus on saving the vast Indian heritage. Their second focus is on increasing earnings of the artisans/designers sitting in remote areas and providing them a global platform to showcase their skills. Third, boosting capital from investors by showcasing a unique platform to have a good amount of money invested by them and have maximum crowd for their website by providing the best services with bare minimum interruptions. Now, the better way to increase the traffic is not only by the products and services rather by making customers feel that they are being cared and their ideas are welcomed. This phenomenon should be made visible and known.

e) Delivery

Craftsvilla is a live example of winning the consumer confidence through their delivery model. They continuously are putting effort to have a fast delivery model since competing on delivery grounds becomes easy for other online players. The same way, once the order is placed online, customers can't really wait to have their packet in hand, so it is a two-way competition. It is the logistics part of the company that takes care of the time taken (to minimize it) during the order and delivery process. Online portals must make it sure that they compete by enhancing the customer reach in a minimum possible time.

At the end of the day when we are talking of co-creation, it's all about a deal, a winwin model, because every initiative in a firm takes place by the people, with the people, and for the people. We should be able to answer every question. Who all are we dealing with? And, who all are we doing it for? Although it is not possible to put everyone at the central place, but we should be able to justify efforts of everyone we involve. Everything said and done should also furnish answers to what stakeholders expect from innovation capacity of any firm, specifically the type of innovation and the difference it has made.

\subsection{What Motivates Cocreation Contributors}

If we consider co-creation as a process in any organization, our focus should include everything from having skilled employees to having skilled customers. Following are the factors identified by researchers. Which enables and encourages different parties to come together and collaborate, Directly and indirectly.

\begin{tabular}{|c|c|}
\hline Customers & Investors \\
\hline $\begin{array}{l}\text { Skilled employees } \\
\text { Online platform to collaborate } \\
\text { Customer engagement through various touch points } \\
\text { Creating awareness for such collaborations } \\
\text { Idea generation, recognition and acknowledgement } \\
\text { Clear communication of values and costs Involved } \\
\text { (Simoes-Brown, 2011) } \\
\text { Key brands vs. creating own brands }\end{array}$ & $\begin{array}{l}\text { Growing use of internet } \\
\text { Accumulated interest of investors } \\
\text { Founder's passion vs. investor's goal behind } \\
\text { investment } \\
\text { Market opportunities and profit sharing } \\
\text { Non-replicable horizontal business model }\end{array}$ \\
\hline Artisans & Employees \\
\hline $\begin{array}{l}\text { Simple people with limited needs } \\
\text { Generally happy } \\
80 \% \text { woman entrepreneurs } \\
\text { Preserving culture and tradition through product } \\
\text { showcase } \\
\text { Strong relationship with organization } \\
\text { Proper tools to measure artisan engagement }\end{array}$ & $\begin{array}{l}\text { Central representatives } \\
\text { Healthy positive environment } \\
\text { Regular interaction with founders } \\
\text { Extra facilities to ensure good health } \\
\text { Continuous seller support } \\
\text { Freedom to express ideas } \\
\text { Focused approach to excel together } \\
\text { Culture of collaboration and participation } \\
\text { Employees first } \\
\text { Everyone equals }\end{array}$ \\
\hline
\end{tabular}




\section{Limitations and Scope for Future Study}

The present study is focused on individual company involved in co-creation. The generalization arrived at can be supported and further strengthened by analyzing more companies and by doing empirical research to explore and examine additional variables, if any. Literature suggests that conceptual studies are done to establish the basis for further studies. Some important areas for future research are consumer intuition and intentions to find out if the customer is always right, to explore how to have right consumer representatives, and strategies to grab numerous ideas and suggestions available at the market place. In the light of this paper researchers further can interview founders to understand the innovation and entrepreneurship eco-system in India. What are the barrier they faced and what were their overcome strategies? and develop a case-study.

\section{References}

Co-creation design as a new way of value creation, 14 (European Comission February 2014).

Devedi, P. S. (2017). A study on Parameters of Online Reviews content that influence consumers buying behaviour- An Indian Perspective. Journal of business and retail managment research.

Lindegaard, S. (2013, August 30). Retrieved from opensource.com:

https:/ /opensource.com/business/13/6/three-free-books-innovation

Pathak, R., \& Sharma, M. (2016). Kohler Innovate the Consumer Way: Because Hands are made For Love. International Journal of Business and Social Science, 280-288.

Prahlad, C. R. (2004). Co-Creation Experiences: The Next Practice in Value Creation. Journal of Interactive Marketing, 8(3).

Simoes-Brown, D. H. (2011). Start at the end. In P. Sloane, A guide to open innovation and crowdsourcing (pp. 43-49). Great Britain: Kogan Page.

\section{Endnotes}

'https://www.facebook.com/pg/craftsvilla/likes/?ref=page_internal (Latest updated on 21 st March 2017)

ithttp:/ / www.adageindia.in/marketing/cmo-strategy/Craftsvilla-eyes-female-ethnicwear-marketwith-rs-100-crore-media-plan/articleshow/49174434.cms (accessed on 24 May 2016).

iiihttp:/ / startupbeat.com/2012/07/04/with-1-5-million-in-recently-raised-series-a-funds-in-thebank-Craftsvilla-is-building-a-marketplace-for-unique-products-from-india/ (accessed on 23 May 2016).

ivhttp://www.josic.com/indias-ecommerce-market-expected-to-top-thirtyeight-billion-in678-newyear (accessed on 25 October 2015).

vhttps://www.owler.com/iaApp/234952/Craftsvilla-competitors?onBoardingComplete=true (accessed on 3 Feb 2016).

vihttp:/ / www.livemint.com/Industry/p5bKwMUdBOOkAjwxTVsWZP/Why-investors-are-bettingbig-on-Indian-ecommerce-firms.html accessed on (19 December 2015).

vii http:/ / www.josic.com/indias-ecommerce-market-expected-to-top-thirtyeight-billion-in678-newyear (accessed on 23 October 2015).

viiihttp:/ / www.mydigitalfc.com/news/home-and-overseas-ethnic-wear-new-rage-768 (accessed on 9 May 2016).

ixShashwati Shankar, ET Bureau 28 December 2015.

×BejulSomaia, Managing Director of Lightspeed India Partners Advisors.

${ }^{\mathrm{x}}$ http:/ / tech.economictimes.indiatimes.com/news/startups/Craftsvilla-acquires-clothes-rentalcompany-f2so4/52019729 (accessed on 24 May 2016).

xiiSunday Times of India, "Newsmaker of the week, Manoj Gupta: The craft of success," New Delhi, 28 February 2016.

xiiihttp:/ / tech.economictimes.indiatimes.com/news/startups/Craftsvilla-acquires-clothes-rentalcompany-f2so4/52019729 (accessed on 24 May 2016). 
http:/ / www.forbes.com/sites/ ashoka/2014/02/04/why-co-creation-is-the-future-for-all-ofus/\#17cf27c2478e

xv http://www.businessdictionary.com/definition/co-creation.html

xvihttps:/ / timreview.ca/article/302

xvii http:/ / frankpiller.com/customer-co-creation/

xviii https:/ / hbr.org/2010/10/building-the-co-creative-enterprise

xixfile:/ / C:/Users/Ruchi\%20Gautam\%20Pant/Downloads/14-dfi-co-creation-design-as-a-way-ofvalue-creation_en.pdf

${ }^{\mathrm{xx}} \mathrm{http}$ :/ / startupbeat.com/2012/07/04/with-1-5-million-in-recently-raised-series-a-funds-in-thebank-Craftsvilla-is-building-a-marketplace-for-unique-products-from-india/ (accessed on 16 January 2016).

xxihttp:/ /articles.economictimes.indiatimes.com/2015-12-28/news/69356583_1_50-lakhs-nexusventure-manoj-gupta (accessed on 3 January 2016).

xxii http:/ / www.franchiseindia.com/entrepreneur/news/Ethnic-eCommerce-portal-Craftsvilla-comraises-Rs-100-crore-Series-B-fund-6324/ (accessed on 3 January 2016).

xxiii http:/ / www.frugal-innovation.com/what-is-frugal-innovation/

${ }^{\text {xxiv }}$ http:/ / www.indiainfoline.com/article/ news-top-story/Craftsvilla-com-becomes-the-onlyprofitable-ecommerce-company-in-india-114020500230_1.html (accessed on 7 March 2016).

${ }^{x \times v}$ http://www.tantum.com/tantum/pdfs/2009/2_the_co_creation_connection.pdf last (accessed on 27 May 2016). 